\title{
The Respiratory Burst and Its Physiological Significance
}




\section{The Respiratory Burst and Its Physiological Significance}

\section{Edited by}

\section{Anthony J. Sbarra}

St. Margaret's Hospital for Women

and Tufts University School of Medicine

Boston, Massachusetts

\section{and}

\section{Robert R. Strauss}

Clinical Pathology Facility, Inc.

Pittsburgh, Pennsylvania

Plenum Press • New York and London 
The Respiratory burst and its physiological significance / edited by Anthony J. Sbarra and Robert R. Strauss.

p. $\quad \mathrm{cm}$.

Includes bibliographies and index.

ISBN-13: 978-1-4684-5498-7 e-ISBN-13: 978-1-4684-5496-3

DOI: $10.1007 / 978-1-4684-5496-3$

1. Phagocytes-Metabolism. 2. Cell respiration. 3. Active oxygen-Physiological effect. 4. Phagocytosis. I. Sbarra, Anthony J. II. Strauss, Robert R.

[DNLM: 1. Oxygen Consumption. 2. Phagocytes-physiology. WF 110 R434]

QR185.8.P45R47 1988

$616.07^{\prime} 9-\mathrm{dc} 19$

DNLM/DLC

88-22476

for Library of Congress

CIP

(C) 1988 Plenum Press, New York

Softcover reprint of the hardcover 1st edition 1988

A Division of Plenum Publishing Corporation

233 Spring Street, New York, N.Y. 10013

All rights reserved

No part of this book may be reproduced, stored in a retrieval system, or transmitted in any form or by any means, electronic, mechanical, photocopying, microfilming, recording, or otherwise, without written permission from the Publisher 


\section{Contributors}

PAOLO BELLAVITE - Institute of General Pathology, University of Verona, 37134 Verona, Italy

GIORGIO BERTON - Institute of General Pathology, University of Verona, 37134 Verona, Italy

BEN G. J. M. BOLSCHER - Central Laboratory of the Netherlands Red Cross Blood Transfusion Service and Laboratory of Experimental and Clinical Immunology, University of Amsterdam, 1006 AK Amsterdam, The Netherlands

NIELS BORREGAARD - Department of Medicine and Hematology C, Gentofte Hospital, University of Copenhagen, DK-2900 Hellerup, Denmark

BRADLEY E. BRITIGAN - Department of Medicine, University of North Carolina, Chapel Hill, North Carolina 27514

CURTIS L. CETRULO - Department of Maternal Fetal Medicine, St. Margaret's Hospital for Women, Boston, Massachusetts 02125 and Department of Obstetrics and Gynecology, Tufts University School of Medicine, Boston, Massachusetts 02125

ANJAN CHAUDHURY - Department of Maternal Fetal Medicine, St. Margaret's Hospital for Women, Boston, Massachusetts 02125 and Department of Obstetrics and Gynecology, Tufts University School of Medicine, Boston, Massachusetts 02125

MYRON S. COHEN - Departments of Medicine and Microbiology and Immunology, Division of Infectious Diseases, University of North Carolina, Chapel Hill, North Carolina 27514

ALDO DOBRINA • Institute of General Pathology, University of Trieste, 34127 Trieste, Italy

STEFANO DUSI • Institute of General Pathology, University of Verona, 37134 Verona, Italy 
GABRIELLA FÓRIS - First Department of Medicine, University Medical School, 4012 Debrecen, Hungary

TAMÁS FÜLÖP, Jr. • First Department of Medicine, University Medical School, 4012 Debrecen, Hungary

LEO I. GORDON - Department of Medicine, Section of Hematology/Oncology and the Cancer Center, Northwestern University Medical School, Chicago, Illinois 60611

KENT J. JOHNSON • Department of Pathology, University of Michigan Medical School, Ann Arbor, Michigan 48109-0650

JOSEPH L. KENNEDY, JR. - Department of Pediatics, St. Margaret's Hospital for Women, Boston, Massachusetts 02125

MARK S. KEMPNER - Department of Medicine, Tufts-New England Medical Center, Boston, Massachusetts 02111

ÉVA M. KOVÁCS - First Department of Medicine, University Medical School, 4012 Debrecen, Hungary

ANDRÁS LEÖVEY - First Department of Medicine, University Medical School, 4012 Debrecen, Hungary

CHARLES J. LOCKWOOD - Department of Maternal Fetal Medicine, St. Margaret's Hospital for Women, Boston, Massachusetts 02125 and Department of Obstetrics and Gynecology, Tufts University School of Medicine, Boston, Massachusetts 02125

FARID LOUIS - Department of Pathology, St. Margaret's Hospital for Women, Boston, Massachusetts 02125

RENÉ LUTTER - Central Laboratory of the Netherlands Red Cross Blood Transfusion Service and Laboratory of Experimental and Clinical Immunology, University of Amsterdam, 1006 AK Amsterdam, The Netherlands

RENZO MENEGAZZI - Institute of General Pathology, University of Trieste, 34127 Trieste, Italy

JÓZSEF T. NAGY - First Department of Medicine, University Medical School, 4012 Debrecen, Hungary

VICTOR A. NAJJAR - Department of Molecular Biology and Microbiology, Tufts University School of Medicine, Boston, Massachusetts 02111

PETER J. O'BRIEN - Faculty of Pharmacy, University of Toronto, Toronto, Ontario M5S 1A1, Canada

GEORGE PARAGH - First Department of Medicine, University Medical School, 4012 Debrecen, Hungary

PIERLUIGI PATRIARCA - Institute of General Pathology, University of Trieste, 34127 Trieste, Italy 
MARK T. PETERS • Department of Maternal Fetal Medicine, St. Margaret's Hospital for Women, Boston, Massachusetts 02125 and Department of Obstetrics and Gynecology, Tufts University School of Medicine, Boston, Massachusetts 02125

DIRK ROOS • Central Laboratory of the Netherlands Red Cross Blood Transfusion Service and Laboratory of Experimental and Clinical Immunology, University of Amsterdam, 1006 AK Amsterdam, The Netherlands

ARTHUR L. SAGONE, Jr. - Department of Medicine and Pharmacology, Division of Hematology and Oncology, Ohio State University, College of Medicine, Columbus, Ohio 43210

ANTHONY J. SBARRA - Department of Medical Research and Laboratories, St. Margaret's Hospital for Women, Boston, Massachusetts 02125 and Department of Obstetrics and Gynecology, Tufts University School of Medicine, Boston, Massachusetts 02125

RUDOLF E. SCHOPF • Department of Dermatology, Johannes Gutenberg University, D-6500 Mainz, West Germany

BENNETT M. SHAPIRO - Department of Biochemistry, University of Washington, Seattle, Washington 98195

CHRIS J. SHAKR • Department of Maternal Fetal Medicine, St. Margaret's Hospital for Women, Boston, Massachusetts 02125 and Department of Obstetrics and Gynecology, Tufts University School of Medicine, Boston, Massachusetts 02125

EMIL SKAMENE • Division of Clinical Immunology and Allergy, The Montreal General Hospital, Montreal, Québec H3G 1A4, Canada

STANLEY D. SOMERFIELD • Division of Clinical Immunology and Allergy, The Montreal General Hospital, Montreal, Québec H3G 1A4, Canada

TERESA STELMASZYŃSKA • Institute of Medical Biochemistry, Nicolaus Copernicus Academy of Medicine, 31-034 Kraków, Poland

BARBARA STYRT • Department of Medicine, Michigan State University, East Lansing, Michigan 48824-1317

GAIL THOMAS • Department of Medical Research and Laboratories, St. Margaret's Hospital for Women, Boston, Massachusetts 02125 and Department of Obstetrics and Gynecology, Tufts University School of Medicine, Boston, Massachusetts 02125

ERIC E. TURNER • Department of Biochemistry, University of Washington, Seattle, Washington 98195

JACK P. UETRECHT • Faculties of Pharmacy and Medicine, University of Toronto and Sunnybrook Hospital, Toronto, Ontario M5S 1A1, Canada 
ZSUZSA VARGA - First Department of Medicine, University Medical School, 4012 Debrecen, Hungary

HORN-WEN WANG - Department of Maternal Fetal Medicine, St. Margaret's Hospital for Women, Boston, Massachusetts 02125 and Department of Obstetrics and Gynecology, Tufts University School of Medicine, Boston, Massachusetts 02125

PETER A. WARD - Department of Pathology, University of Michigan Medical School, Ann Arbor, Michigan 48109-0650

JEFFREY S. WARREN - Department of Pathology, University of Michigan Medical School, Ann Arbor, Michigan 48109-0650

SIGMUND A. WEITZMAN - Department of Medicine, Section of Hematology/Oncology and the Cancer Center, Northwestern University Medical School, Chicago, Illinois 60611

GIULIANO ZABUCCHI - Institute of General Pathology, University of Trieste, 34127 Trieste, Italy

JAN MACIEJ ZGLICZYŃSKI - Institute of Medical Biochemistry, Nicolaus Copernicus Academy of Medicine, 31-034 Kraków, Poland 


\section{Preface}

When phagocytes are exposed to a number of different stimuli, they undergo dramatic changes in the way they process oxygen. Oxygen uptake increases markedly, frequently more than 50 -fold; the phagocytes begin to produce large quantities of superoxide and hydrogen peroxide; and they immediately begin to metabolize large amounts of glucose by way of the hexose monophosphate shunt. This series of changes has become known as the respiratory burst. It was first believed that the major function of this respiratory burst was to generate powerful antibacterial agents by the partial reduction of oxygen. It is becoming apparent that the respiratory burst has much wider application, and its physiological function in many different biological areas is clear. In this volume, we have attempted to bring together the work of experts who have published extensively on the involvement of the respiratory burst in different physiological functions.

In the first three chapters, Dr. Borregaard and Dr. Berton and co-workers and Dr. Roos and co-workers bring together what is known about the respiratory burst. They present up-to-date versions of the biochemical and metabolic activities associated with the burst. In Chapter 4, Dr. Styrt and Dr. Klempner discuss the respiratory burst as it affects cellular ion homeostasis. Dr. Cohen and Dr. Britigan (Chapter 5) present some interesting data on the competition between the respiratory burst and bacteria for oxygen. Dr. Dobrina and Dr. Patriarca (Chapter 6) describe the involvement of the respiratory burst in the damaging of endothelial cells. Dr. Zabucchi, Dr. Menegazzi, and Dr. Patriarca (Chapter 7) discuss the respiratory burst and the eosinophils, evaluating comparisons between the eosinophils and the neutrophil.

Dr. Sagone (Chapter 8) discusses the possible effects of the reactive oxygen species resulting from the respiratory burst on the functional capacity of lymphocytes. Dr. Somerfield and Dr. Skamene (Chapter 9) present data concerning the modulation of the respiratory burst by naturally occurring substances. In Chapter 10 , Dr. O'Brien discusses the oxidants formed by the respiratory burst and their physiological involvement in the oxidative metabolism and activation of drugs, 
carcinogens, and xenobiotics. Drug-induced agranulocytosis and other effects mediated by peroxidases during the respiratory burst are discussed by Dr. Uetrecht in Chapter 11. Dr. Sagone (Chapter 12) discusses the capacity of granulocytes to metabolize xenobiotics and further discusses the possible clinical implication of this. Dr. Gordon and Dr. Weitzman (Chapter 13) review evidence implicating oxygen-derived free radicals in carcinogenesis.

Dr. Warren, Dr. Ward, and Dr. Johnson discuss in Chapter 14 how phagocytes generate oxygen-derived radicals and how they are important mediators of tissue damage. Dr. Zgliczyński and Dr. Stelmaszyńska (Chapter 15) discuss the influence of the respiratory burst on infected tissue.

In Chapter 16, Dr. Schopf presents data involving the respiratory burst of phagocytes in the inflammatory reaction in psoriasis. The special role of reactive oxygen species in diabetes mellitus is discussed by Dr. Nagy, Dr. Fülöp, Dr. Paragh, and Dr. Fóris in Chapter 17. Dr. Turner and Dr. Shapiro (Chapter 18) discuss the involvement of the respiratory burst in fertilization. The respiratory burst and the development of generalized atherosclerosis, a subject that is beginning to receive serious consideration, is presented by Dr. Paragh, Dr. Kovács, Dr. Nagy, Dr. Fóris, and Dr. Fülöp in Chapter 19. Aging and reactive oxygen species associated with the respiratory burst are discussed by Dr. Fülöp, Dr. Fóris, Dr. Nagy, and Dr. Leövey in Chapter 20. Dr. Cetrulo and colleagues (Chapter 21) present evidence that implicates the respiratory burst in the onset of human labor, preterm labor, and premature rupture of the membranes. In Chapter 22, Dr. Najjar discusses the biochemical and biological aspects of tuftsin, a powerful chemoattractant that can enhance the respiratory burst of neutrophils in the presence of other soluble or particulate stimuli. We are most grateful to all of the contributors for their contributions.

Boston and Pittsburgh

Anthony J. Sbarra

Robert R. Strauss 


\section{Contents}

\section{The Respiratory Burst: An Overview}

Niels Borregaard

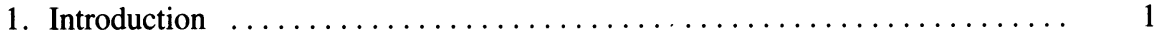

2. Biochemical Activities Associated with the Respiratory Burst $\ldots \ldots \ldots \ldots \ldots 2$

2.1. Origin of Electrons for the Respiratory Burst Oxidase $\ldots \ldots \ldots \ldots, 2$

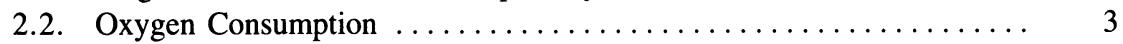

2.3. $\mathrm{O}_{2}^{-}$Generation $\ldots \ldots \ldots \ldots \ldots \ldots \ldots \ldots \ldots \ldots \ldots \ldots \ldots \ldots \ldots, 4$

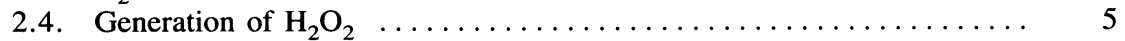

2.5. Myeloperoxidase-Mediated Reactions $\ldots \ldots \ldots \ldots \ldots \ldots \ldots \ldots, 6$

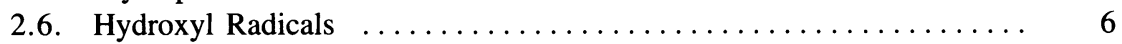

2.7. Chemiluminescence $\ldots \ldots \ldots \ldots \ldots \ldots \ldots \ldots \ldots \ldots \ldots \ldots, \ldots$

2.8. Formation of Chloramines $\ldots \ldots \ldots \ldots \ldots \ldots \ldots \ldots \ldots \ldots, 8$

2.9. Proton Transport during the Respiratory Burst $\ldots \ldots \ldots \ldots \ldots \ldots, 8$

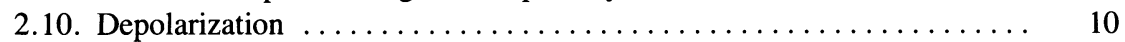

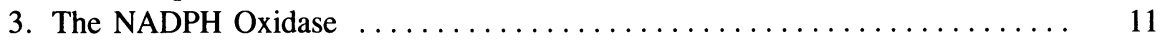

3.1. The NADPH Oxidase as an Electron-Transport Chain $\ldots \ldots \ldots \ldots \ldots \quad 12$

3.2. Subcellular Localization of the NADPH Oxidase and Its Components .. 15

3.3. Activation of the NADPH Oxidase $\ldots \ldots \ldots \ldots \ldots \ldots \ldots \ldots \ldots . \ldots \ldots$

4. Kinetics of the Respiratory Burst $\ldots \ldots \ldots \ldots \ldots \ldots \ldots \ldots \ldots \ldots \ldots \ldots \ldots \ldots$

5. Development of the Ability to Generate a Respiratory Burst $\ldots \ldots \ldots \ldots \ldots, 18$

6. The Respiratory Burst in Nonphagocytic Cells $\ldots \ldots \ldots \ldots \ldots \ldots \ldots \ldots . . \ldots 19$

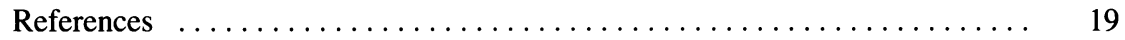

\section{The Respiratory Burst of Phagocytes} Giorgio Berton, Stefano Dusi, and Paolo Bellavite

1. Features of the Respiratory Burst of Phagocytes $\ldots \ldots \ldots \ldots \ldots \ldots \ldots \ldots, 34$

2. Enzymatic Basis of the Respiratory Burst $\ldots \ldots \ldots \ldots \ldots \ldots \ldots \ldots \ldots \ldots \ldots$ 
2.1. Major Properties of NADPH Oxidase, the $\mathrm{O}_{2}^{-}$-Generating

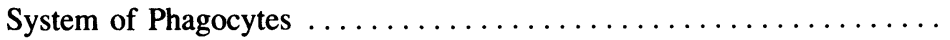

2.2. Activity of the NADPH Oxidase in Relationship to the Respiratory Burst of Intact Phagocytes

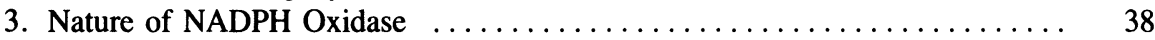

3.1. An $\mathrm{O}_{2}^{-}$-Forming Electron-Transfer Chain $\ldots \ldots \ldots \ldots \ldots \ldots \ldots \ldots \ldots$

3.2. Molecular Structure of NADPH Oxidase $\ldots \ldots \ldots \ldots \ldots \ldots \ldots \ldots .40$

4. Mechanisms of Activation of the Respiratory Burst ............. 41

5. Biological Significance of the Respiratory Burst of Phagocytes ........ 44

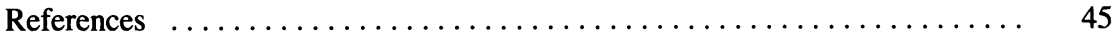

3. The Respiratory Burst and the NADPH Oxidase of Phagocytic Leukocytes

Dirk Roos, René Lutter, and Ben G. J. M. Bolscher

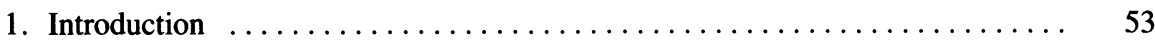

2. Intracellular Killing of Microorganisms $\ldots \ldots \ldots \ldots \ldots \ldots \ldots \ldots \ldots \ldots$

2.1. Production of Reduced Oxygen Species $\ldots \ldots \ldots \ldots \ldots \ldots \ldots \ldots \ldots$

2.2. Fusion of Granules with the Developing Phagosome ........... 56

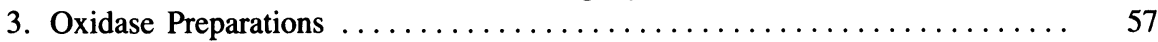

3.1. Properties of Particulate and Detergent-Treated Particulate

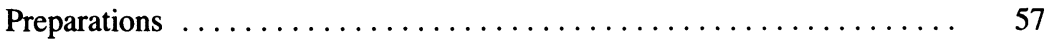

3.2. Properties of Solubilized Oxidase Preparations $\ldots \ldots \ldots \ldots \ldots \ldots \ldots .59$

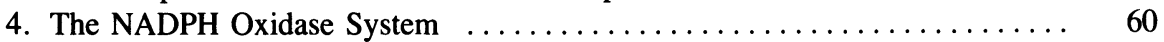

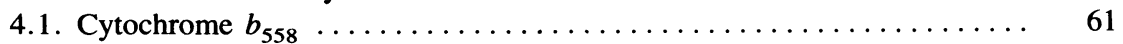

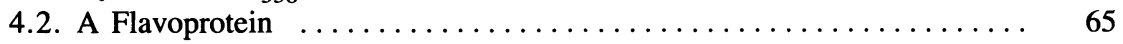

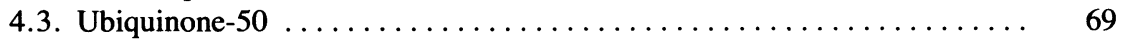

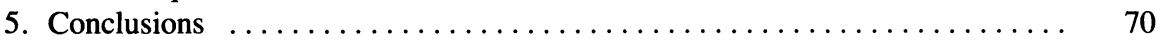

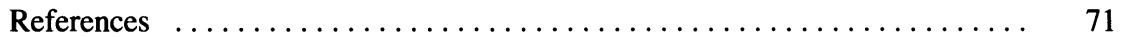

4. The Respiratory Burst and Cellular Ion Homeostasis Barbara Styrt and Mark S. Klempner

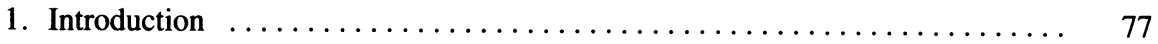

2. Ion Distribution in the Resting Neutrophil $\ldots \ldots \ldots \ldots \ldots \ldots \ldots \ldots \ldots$

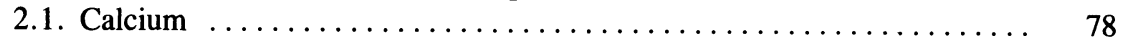

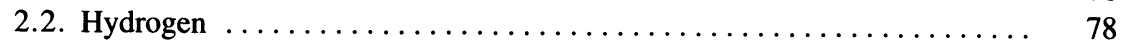

2.3. Sodium, Potassium, and the Membrane Potential ............. 79

3. Ionic Events during Activation of the Respiratory Burst $\ldots \ldots \ldots \ldots \ldots \ldots \quad 80$

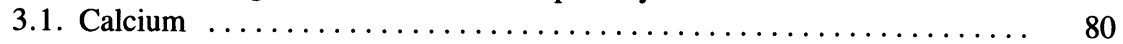

3.2. Hydrogen $\ldots \ldots \ldots \ldots \ldots \ldots \ldots \ldots \ldots \ldots \ldots \ldots \ldots \ldots \ldots \ldots . \ldots \ldots$

3.3. Sodium, Potassium, and the Membrane Potential ........... 87

3.4. Other Ion Systems $\ldots \ldots \ldots \ldots \ldots \ldots \ldots \ldots \ldots \ldots \ldots \ldots \ldots$

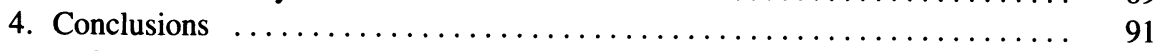

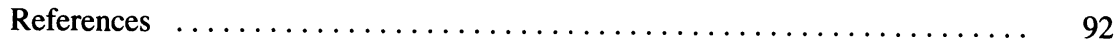


5. An Expanded View of the Phagocytic Respiratory Burst: Bacterial Competition for Oxygen and Its Stimulation by Host Factor(s) Myron S. Cohen and Bradley E. Britigan

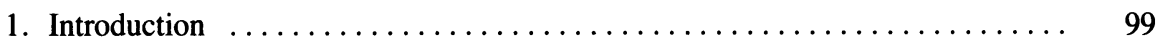

1.1. Microbial Strategies to Resist Oxygen-Dependent Killing . . . . . . ... 99

2. Bacterial Competition for Oxygen $\ldots \ldots \ldots \ldots \ldots \ldots \ldots \ldots \ldots \ldots \ldots \ldots \ldots \ldots$

2.1. Limitations of Interpretation ....................... 107

3. Characterization and Purification of Serum Factor(s) That Enhance Bacterial

Competition for Oxygen ............................ 108

4. Interaction with Myeloid Cells Increases Bacterial

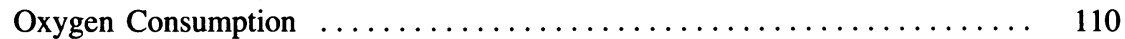

5. Summary and Conclusions $\ldots \ldots \ldots \ldots \ldots \ldots \ldots \ldots \ldots \ldots \ldots \ldots \ldots \ldots \ldots, 113$

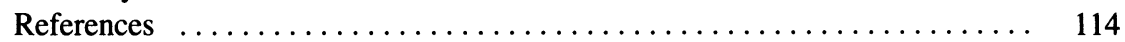

6. The Respiratory Burst and Endothelial Cells Aldo Dobrina and Pierluigi Patriarca

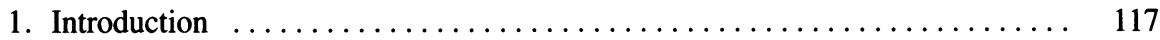

2. Effect of Activated Neutrophils on Endothelial Cells .............. 117

2.1. In Vitro Studies ..................................... 117

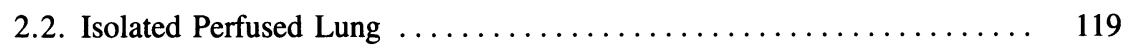

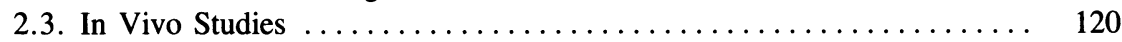

3. Mechanism(s) of Endothelial Damage by Neutrophil Activation ......... 123

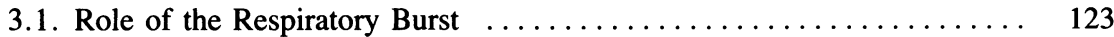

3.2. Role of Neutrophil Proteases ........................ 124

3.3. Cooperation between ROI-Dependent and Protease-Dependent

Mechanisms .................................. 125

4. Protective Mechanisms of Endothelial Cells against the Neutrophil

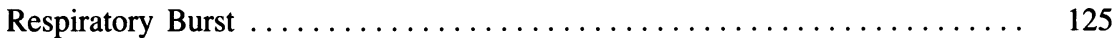

4.1. Inhibition of the Neutrophil Respiratory Burst by Endothelial Cells .... 125

4.2. Endothelial Cell Mechanisms for $\mathrm{O}_{2}^{-} \cdot$ and $\mathrm{H}_{2} \mathrm{O}_{2}$ Degradation $\ldots \ldots \ldots, 126$

5. Interactions of Neutrophils with Endothelium .................. 127

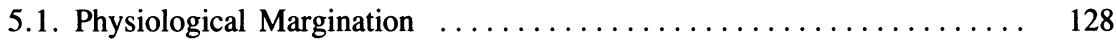

5.2. Neutrophil-Endothelium Interaction during Diapedesis $\ldots \ldots \ldots \ldots, 128$

5.3. Interaction of Neutrophils with Altered Endothelial Cells .......... 128

5.4. Intravascular Activation of Neutrophils .................... 129

5.5. Extravascular Activation of Neutrophils $\ldots \ldots \ldots \ldots \ldots \ldots \ldots \ldots, 130$

6. Relationships to Human Pathology $\ldots \ldots \ldots \ldots \ldots \ldots \ldots \ldots \ldots \ldots . . \ldots \ldots$

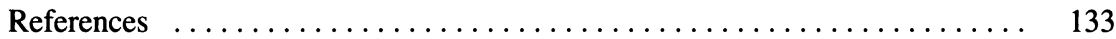

7. The Respiratory Burst of Eosinophils

Giuliano Zabucchi, Renzo Menegazzi, and Pierluigi Patriarca

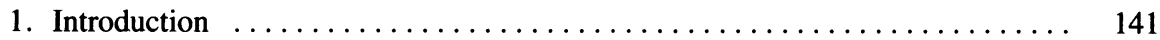

2. Studies with Eosinophils from Eosinophilic Subjects .............. 141 
3. Eosinophils from Normal Subjects versus Eosinophils from Eosinophilic

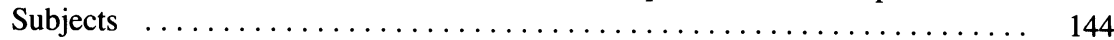

4. Features of the Respiratory Burst of Eosinophils $\ldots \ldots \ldots \ldots \ldots \ldots \ldots \ldots$

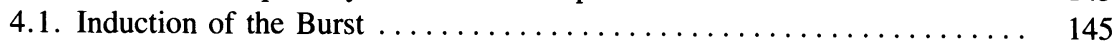

4.2. Products of the Respiratory Burst $\ldots \ldots \ldots \ldots \ldots \ldots \ldots \ldots \ldots \ldots \ldots$

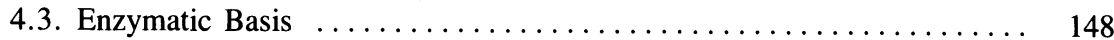

4.4. Enzymes Indirectly Related to the Respiratory Burst . . . . . . . . . . 148

5. Functions of the Respiratory Burst in Eosinophils . . . . . . . . . . . . . . . . . . 149

5.1. Microbicidal and Fungicidal Capacity ....................... 149

5.2. Helminthotoxic Activity . . . . . . . . . . . . . . . . . . . 150

5.3. Regulation of the Activity of the Inflammatory Mediators $\ldots \ldots \ldots \ldots 152$

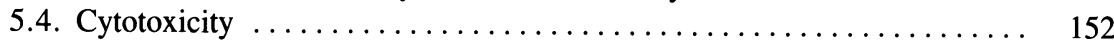

6. Regulation of EPO Concentration in the Extracellular Medium ......... 152

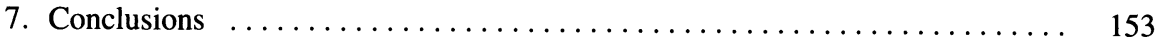

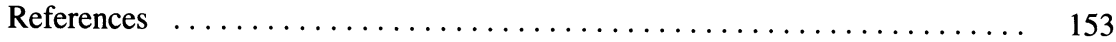

8. The Respiratory Burst and Lymphocyte Function Arthur L. Sagone, Jr.

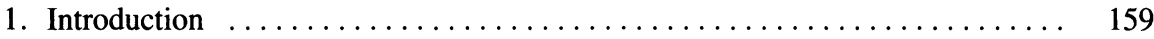

2. Characteristics of the Metabolic Burst ..................... 160

2.1. Nature of the Metabolic Burst in Phagocytic Cells . . . . . . . . . . . . 160

2.2. Generation of ROS by Lymphocytes ................... 162

2.3. Stimuli That Induce a Metabolic Burst in Phagocytic Cells ........ 163

3. Evidence Indicating That the ROS Produced by Phagocytic Cells May Alter the Functional Capacity of Human Lymphocytes . . . . . . . . . . . . . . . . . . . 164

3.1. Effect of Hyperoxia on the Proliferation of Human Lymphocyte Cultures ................................... 165

3.2. Role of ROS in Radiation Damage to Lymphocytes . . . . . . . . . . . 167

3.3. Effect of Chemical Oxidation on Lymphocyte Function $\ldots \ldots \ldots \ldots . . .168$

3.4. Effects of the ROS Generated by Enzyme Systems on the Functional

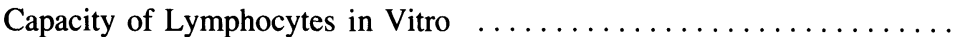

3.5. Possible Differences in the Sensitivity of $\mathrm{T}$ and B Cells to Oxidant

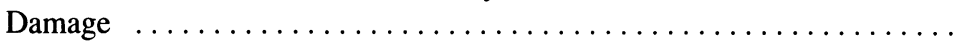

4. Evidence That the Production of ROS by Phagocytic Cells Can Alter

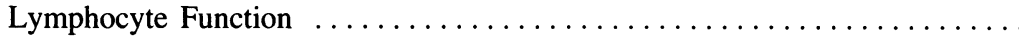

4.1. Evidence That the Release of ROS by Phagocytic Cells May Impair the NK Activity of Lymphocytes .

4.2. Evidence That ROS Released by Phagocytic Cells Can Alter Lymphocyte

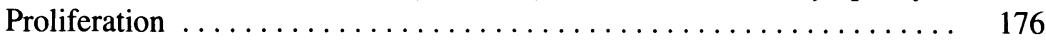

4.3. Role of the Lymphocyte in the Metabolic Burst . . . . . . . . . . . . 180

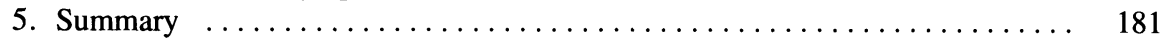

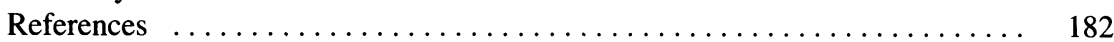




\section{Modulation of the Respiratory Burst by Naturally Occurring Substances}

\section{Stanley D. Somerfield and Emil Skamene}

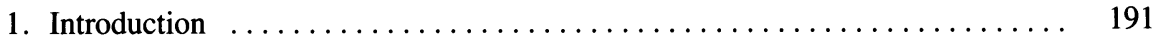

2. Control of Neutrophil Respiratory Burst by Defined Biological Substances ... 192

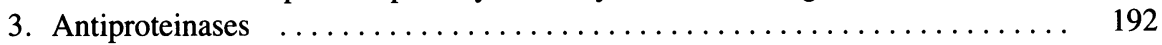

4. Dialyzable Substances in Exudates of Sponge-Induced Inflammation:

Polyamines ....................................... 193

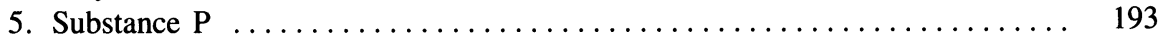

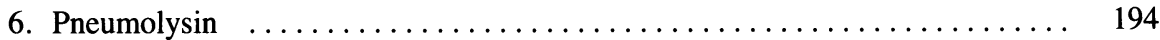

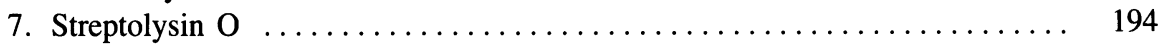

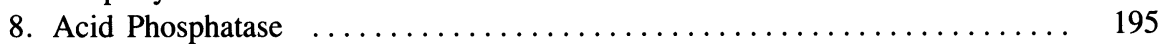

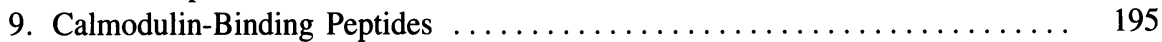

10. Platelet Activating Factor . . . . . . . . . . . . . . . . . . . . . . . . . . . 197

11. Fructose 1,6-Diphosphate ........................... 197

12. Adenosine $\ldots \ldots \ldots \ldots \ldots \ldots \ldots \ldots \ldots \ldots \ldots \ldots \ldots \ldots \ldots \ldots \ldots$

13. Modulation of Respiratory Burst by Viral Products . . . . . . . . . . . 198

14. Summary and Conclusions $\ldots \ldots \ldots \ldots \ldots \ldots \ldots \ldots \ldots \ldots \ldots . \ldots \ldots \ldots$

References ..................................... 199

10. Oxidants Formed by the Respiratory Burst: Their Physiological Role and Their Involvement in the Oxidative Metabolism and Activation of Drugs, Carcinogens, and Xenobiotics Peter J. O'Brien

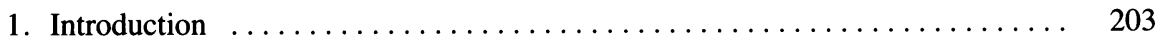

2. Extracellular versus Intracellular Oxidation and Halogenation $\ldots \ldots \ldots \ldots \ldots 205$

3. Trapping Active Chlorine Generated by the Respiratory Burst $\ldots \ldots \ldots \ldots \ldots 206$

4. Physiological Role of Halogenation and Oxidation ............... 209

4.1. Bactericidal Activity and Cell Death .................... 209

4.2. Oxidative Inactivation of Microbial Toxins $\ldots \ldots \ldots \ldots \ldots \ldots \ldots \ldots$

4.3. Oxidative Inactivation of Methionine-Dependent Inflammation Mediators .................................... 215

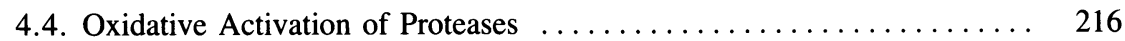

4.5. Inactivation of Prostaglandins and Leukotrienes $\ldots \ldots \ldots \ldots \ldots \ldots \ldots$

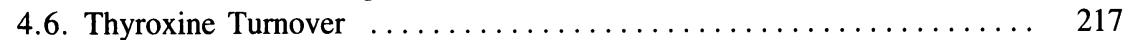

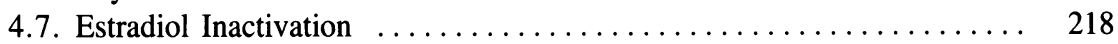

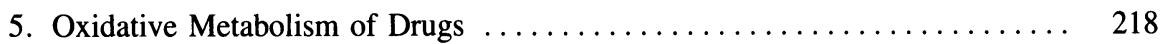

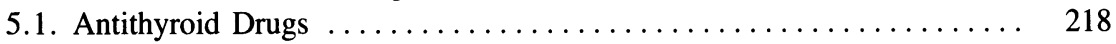

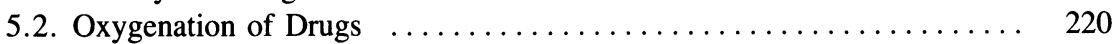

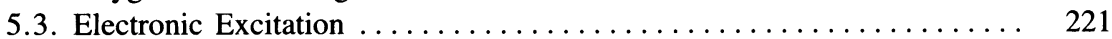

6. Oxidative Activation of Carcinogens and Xenobiotics $\ldots \ldots \ldots \ldots \ldots \ldots 223$

6.1. Arylamines and Phenol ....................... 223 


\section{Drug-Induced Agranulocytosis and Other Effects Mediated by Peroxidases during the Respiratory Burst}

\section{Jack $P$. Uetrecht}

1. Metabolism of Drugs to Reactive Intermediates

2. Pharmacological Effects of Dapsone and Other Arylamines Mediated by Myeloperoxidase

3. Pharmacological and Toxic Effects of Other Drugs Metabolized by Myeloperoxidase

4. Possible Mechanisms of Drug-Induced Agranulocytosis $\ldots \ldots \ldots \ldots \ldots \ldots 237$

4.1. Direct Mechanism ... . . . . . . . . . . . . . . . . . . . . . . . . . . . 237

4.2. Immune-Mediated Mechanism ...................... 237

5. Pharmacological Effects Mediated by Thyroid Peroxidase ........... 238

6. Idiosyncratic Reactions Possibly Due to Metabolism by Monocytes ....... 238

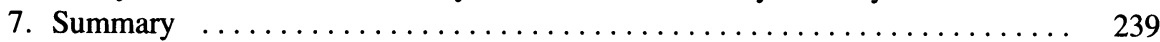

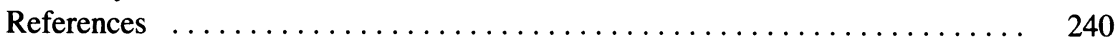

\section{The Respiratory Burst and the Metabolism of Drugs}

\section{Arthur L. Sagone, Jr.}

1. Introduction

2. Characteristics of the Metabolic Burst ................... 246

3. Relevant Studies Concerning the Metabolism of Drugs in Model Systems ... 249

3.1. Horseradish Peroxidase-Hydrogen Peroxide Enzyme System . . . . . . . 249

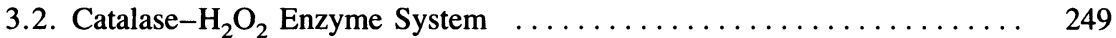

3.3. Arachidonic Acid Metabolism ....................... 250

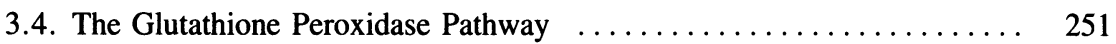

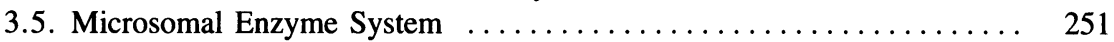

3.6. Xanthine-Xanthine Oxidase Enzyme System ................ 253

3.7. Drug Studies in the Model System-Pulse Radiolysis . . . . . . . . . . . . 254

4. Evidence That the ROS Generated by the Myeloperoxidase System in PMN

Have the Capacity to Metabolize Drugs $\ldots . \ldots \ldots \ldots \ldots \ldots . \ldots . \ldots 257$

5. Evidence That Activated Granulocytes Can Oxidize and Hydroxylate

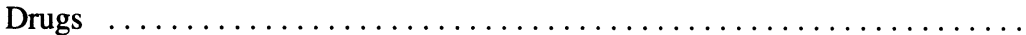

6. Evidence for the Metabolism of Nonsteroidal Anti-inflammatory Drugs by the Hydroxyl Radical Produced by Granulocytes $\ldots \ldots \ldots \ldots \ldots \ldots 261$

7. Metabolism of Drugs by Mononuclear Cells ................. 267

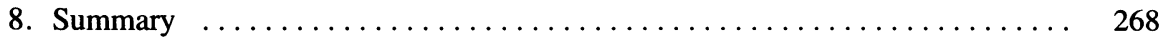

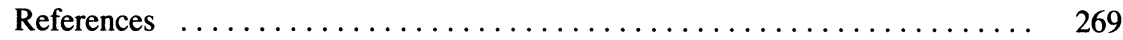




\section{The Respiratory Burst and Carcinogenesis}

\section{Leo I. Gordon and Sigmund A. Weitzman}

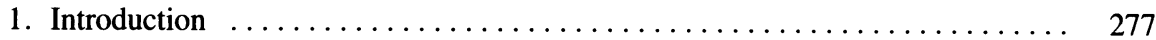

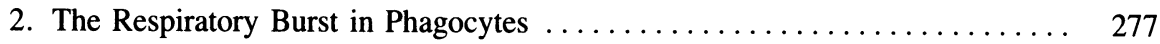

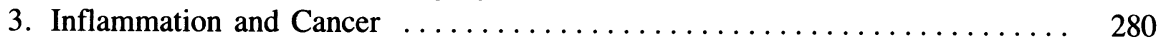

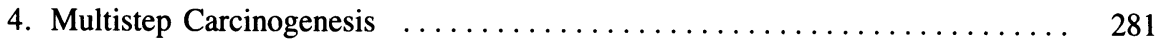

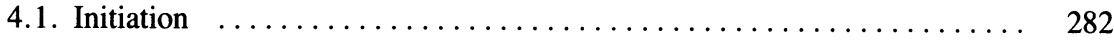

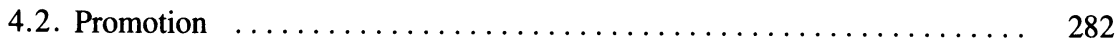

5. Phagocyte-Generated Oxidants in Carcinogenesis ................ 283

5.1. Oxygen-Derived Free Radicals Cause DNA Strand Breaks ......... 283

5.2. Oxygen-Derived Free Radicals Are Mutagenic ............... 284

5.3. Oxygen-Derived Free Radicals Cause Malignant Transformation ...... 285

5.4. Oxygen-Derived Free Radicals Cause Nucleoside Modification ....... 285

5.5. Oxygen-Derived Free Radicals Activate Xenobiotic Procarcinogens to Genotoxic Intermediates .......................... 286

5.6. Oxygen-Derived Free Radicals Cause Chromosomal Abnormalities .... 288

5.7. Oxygen-Derived Free Radicals Act as Tumor Promotors .......... 289

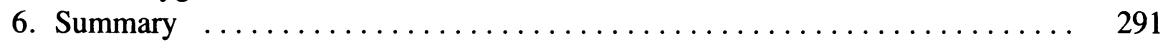

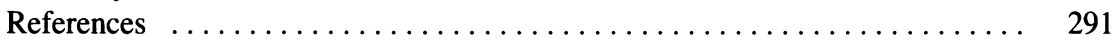

14. The Respiratory Burst and Mechanisms of Oxygen Radical-Mediated Tissue Injury

Jeffrey S. Warren, Peter A. Ward, and Kent J. Johnson

1. Introduction ..................................... 299

2. Oxygen-Derived Metabolite Production by Phagocytic Cells ........... 300

3. Host Antioxidant Defense Mechanisms ..................... 304

4. In Vitro Evidence for Phagocyte-Derived Oxygen Metabolite-Mediated Cell

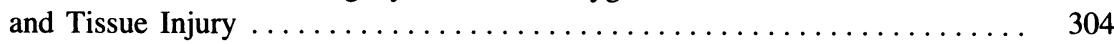

5. In Vivo Models of Oxygen Metabolite-Mediated Tissue Injury ......... 308

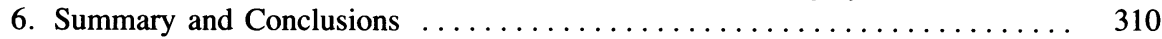
References $\ldots \ldots \ldots \ldots \ldots \ldots \ldots \ldots \ldots \ldots \ldots \ldots \ldots \ldots \ldots \ldots, 311$

15. The Respiratory Burst of Neutrophilic Granulocytes and Its Influence on Infected Tissues: Indirect Consequences Jan Maciej Zgliczyński and Teresa Stelmaszyńska

1. Reactive Species Produced Due to the Respiratory Burst ............ 315

1.1. Triggering the Respiratory Burst $\ldots \ldots \ldots \ldots \ldots \ldots \ldots \ldots \ldots \ldots \ldots \ldots \ldots \ldots$

1.2. Reaction Pathways Originating from the Increased Oxygen Uptake by Neutrophils .................................... 319

1.3. Reactivity of the MPO-Mediated Products of the Respiratory Burst

2. Effects of Respiratory Burst Products on Metabolic Reactions in the Infected Tissues 


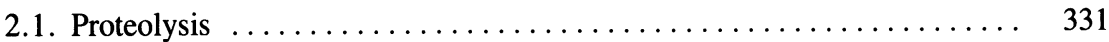

2.2. Changes in Nucleic Acid Metabolism ..................... 334

2.3. Degradation of Proteoglycans $\ldots \ldots \ldots \ldots \ldots \ldots \ldots \ldots \ldots \ldots . . \ldots \ldots$

2.4. Tentative Mechanisms of Cytotoxic and Cytolytic Activities of Neutrophils toward Target Cells $\ldots \ldots \ldots \ldots \ldots \ldots \ldots \ldots \ldots . \ldots \ldots$

3. Modulation of Respiratory Burst by Its Products $\ldots \ldots \ldots \ldots \ldots \ldots \ldots . . \ldots 336$

3.1. The MPO- $\mathrm{H}_{2} \mathrm{O}_{2}-\mathrm{Cl}-$ System as a Modulator of the Respiratory Burst .................................... 336

3.2. Influence of Cyanide on Respiratory Burst and Other Neutrophil

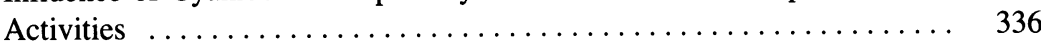

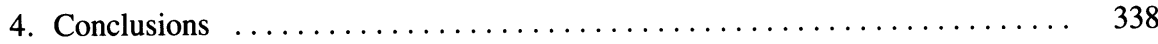

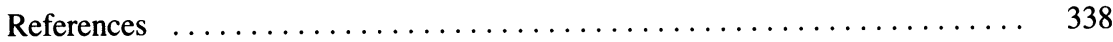

16. The Respiratory Burst and Psoriasis

\section{Rudolf E. Schopf}

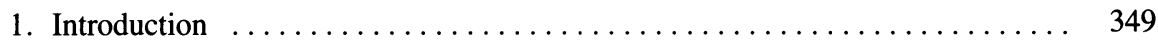

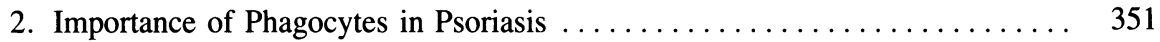

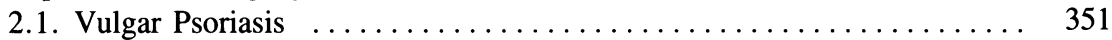

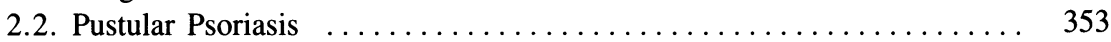

3. Respiratory Burst-Related Peripheral Blood Phagocyte Function in Psoriasis .. 354

3.1. Chemiluminescent Response of PMN in Psoriasis .............. 355

3.2. Chemiluminescent Response of Mononuclear Leukocytes in Psoriasis ... 355

3.3. Effects of Psoriatic Serum on the Respiratory Burst ............ 355

3.4. Activity of G6PD Activity in Mononuclear Leukocytes in Psoriasis ... 356

4. Influence of Epidermal Cell-Culture Supernatants of Psoriatic Skin on the Respiratory Burst of Phagocytes $\ldots \ldots \ldots \ldots \ldots \ldots \ldots \ldots \ldots \ldots \ldots$

5. Effects of Psoriatic Scales on the Respiratory Burst $\ldots \ldots \ldots \ldots \ldots \ldots \ldots, 360$

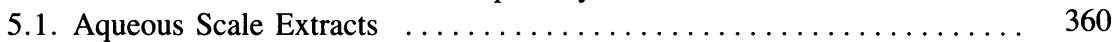

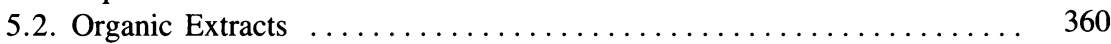

6. Effects of PMN on Keratinocytes $\ldots \ldots \ldots \ldots \ldots \ldots \ldots \ldots \ldots \ldots . \ldots \ldots 2$

6.1. Effect of Extracts of Scales on PMN-Mediated Cytotoxicity of

Keratinocytes ................................... 362

7. Role of the Respiratory Burst in Psoriasis .................... 364

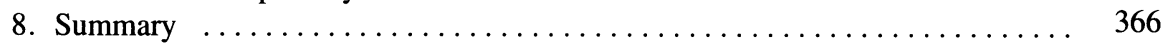

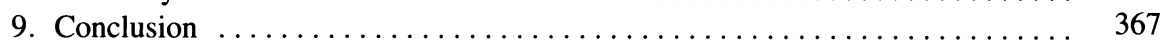

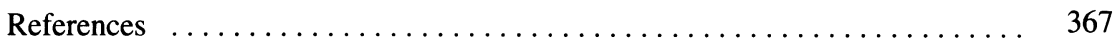

17. The Respiratory Burst and Diabetes Mellitus József T. Nagy, Tamás Fülöp, Jr., George Paragh, and Gabriella Fóris

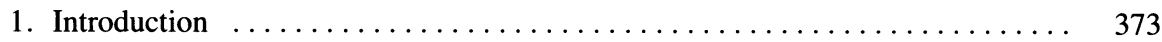

2. Alteration of the Immune System in Diabetes Mellitus $\ldots \ldots \ldots \ldots \ldots \ldots . . \ldots 374$

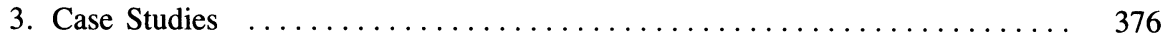

4. Reactive Oxygen Species-Generating System and the Effector Functions of Granulocytes in Diabetes Mellitus ........................ 377

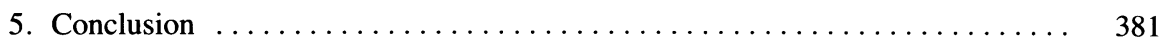

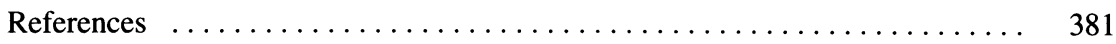




\section{The Respiratory Burst of Fertilization}

\section{Eric E. Turner and Bennett M. Shapiro}

1. Introduction and Historical Perspective $\ldots \ldots \ldots \ldots \ldots \ldots \ldots \ldots \ldots \ldots$

2. The Respiratory Burst and Related Events at Fertilization ........... 388

2.1. Initiation and Kinetics of the Respiratory Burst ............ 388

2.2. Role of Exocytosis and Intracellular $\mathrm{Ca}^{2}+$ in the Respiratory Burst . . . 389

2.3. Activation of NAD Kinase and the Pentose Phosphate Pathway . . . . . . 390

3. Peroxide Production and Fertilization Envelope Hardening . . . . . . . . . 392

3.1. Assembly and Crosslinking of the Fertilization Envelope . . . . . . . 392

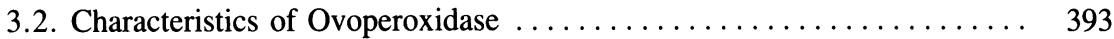

3.3. $\mathrm{H}_{2} \mathrm{O}_{2}$ Production and Chemiluminescence $\ldots \ldots \ldots \ldots \ldots \ldots \ldots \ldots$

4. Possible Mechanisms of the Respiratory Burst ... . . . . . . . . . . . . 395

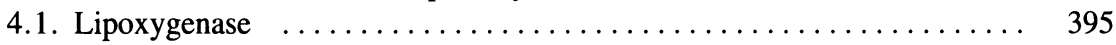

4.2. Oxidase Activity of Ovoperoxidase $\ldots \ldots \ldots \ldots \ldots \ldots \ldots \ldots \ldots \ldots \ldots$

4.3. Other Oxidases . . . . . . . . . . . . . . . . . . . . . . . . . . . . . . . . . 397

4.4. Parallels between Fertilization and Phagocytosis . . . . . . . . . . . . . 397

5. Production of Activated Oxygen and Control of Toxicity ........... 398

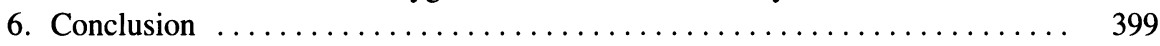

References . . . . . . . . . . . . . . . . . . . . . . . . . . . . . . . 399

19. The Respiratory Burst and Atherosclerosis

George Paragh, Éva M. Kovács, József T. Nagy, Gabriella Fóris, and Tamás Fülöp, Jr.

1. Introduction $\ldots \ldots \ldots \ldots \ldots \ldots \ldots \ldots \ldots \ldots \ldots \ldots \ldots \ldots \ldots \ldots \ldots \ldots \ldots \ldots \ldots$
2. Dual Role of Monocyte-Macrophage System in the Immune Response and in

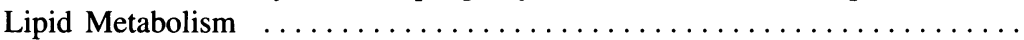

3. Dual Role of EC and SMC in the Immune Response and in Lipid

Metabolism

4. Role of ROS Generation in Atherosclerotic Plaque Formation ...........

5. LDL Particles as Triggers of the Respiratory Burst $\ldots \ldots \ldots \ldots \ldots \ldots \ldots 410$

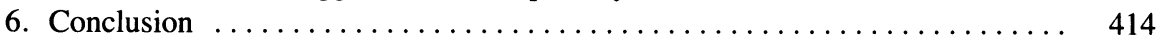

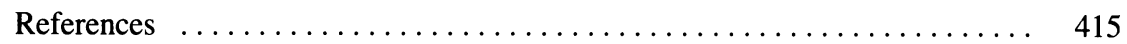

20. The Respiratory Burst and Aging

Tamás Fülöp, Jr., Gabriella Fóris, József T. Nagy, Zsuzsa Varga, and András Leövey

1. Introduction

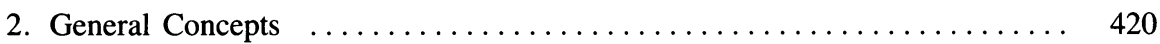

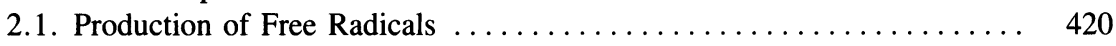

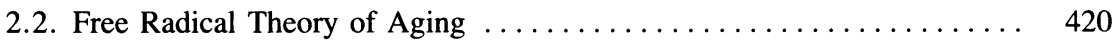

2.3. The Glutathione Redox Cycle $\ldots \ldots \ldots \ldots \ldots \ldots \ldots \ldots \ldots \ldots \ldots . \ldots 421$

3. The Resting Oxidative Metabolism in the PMNL of the Elderly ......... 421

4. The Respiratory Burst during Various Stimulations .............. 423

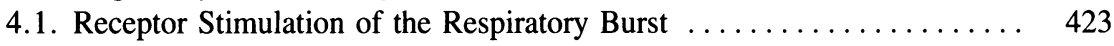

4.2. Nonspecific Stimulation of the Respiratory Burst . . . . . . . . . . . . . 428

4.3. Detoxification of Reactive Oxygen Species . . . . . . . . . . . . . 429 


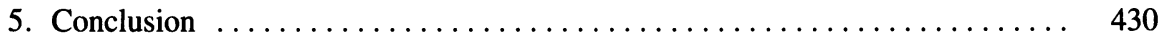

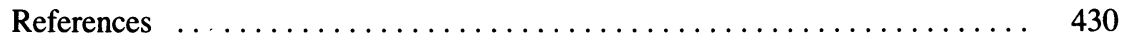

21. The Respiratory Burst and the Onset of Human Labor, Preterm Labor, and Premature Rupture of the Membranes

Curtis L. Cetrulo, Anthony J. Sbarra, Anjan Chaudhury, Mark T.

Peters, Charles J. Lockwood, Gail Thomas, Joseph L. Kennedy, Jr., Farid Louis, Chris J. Shakr, and Horn-Wen Wang

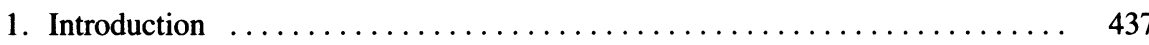

2. Phagocytosis and the Onset of Human Labor $\ldots \ldots \ldots \ldots \ldots \ldots \ldots \ldots . . \ldots 438$

2.1. Experimental Model ............................ 438

2.2. Interaction of Particulate Material and Surfactants with Amnion Cells ... 439

2.3. Release and Function of Amnion Phospholipase $\mathrm{A}_{2}$ : Initiation of Labor at Term

3. Phagocytosis and Premature Rupture of the Membranes $\ldots \ldots \ldots \ldots \ldots \ldots$. 441

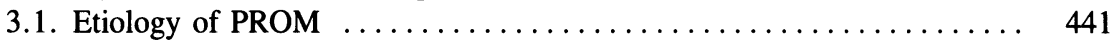

3.2. Role of Peroxidase in PROM ....................... 442

3.3. Surfactant and Fetal Membrane Interactions $\ldots \ldots \ldots \ldots \ldots \ldots \ldots .443$

4. Effect of Bacterial Growth in Fetal Membranes $\ldots \ldots \ldots \ldots \ldots \ldots \ldots \ldots . \ldots 443$

4.1. Experimental Model ............................. 443

4.2. Nature of Effect ................................ 444

5. Summary and Concluding Remarks $\ldots \ldots \ldots \ldots \ldots \ldots \ldots \ldots \ldots \ldots \ldots \ldots \ldots$

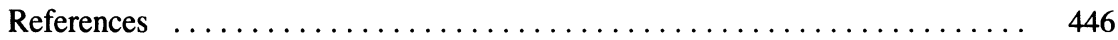

22. Tuftsin: Biochemical and Biological Aspects

Victor A. Najjar

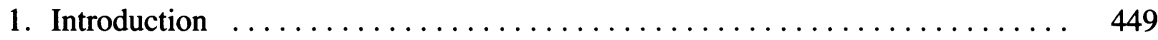

2. General Characteristics of Tuftsin $\ldots \ldots \ldots \ldots \ldots \ldots \ldots \ldots \ldots \ldots, 450$

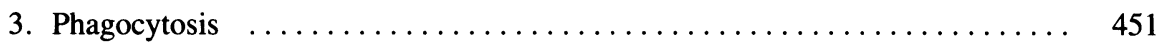

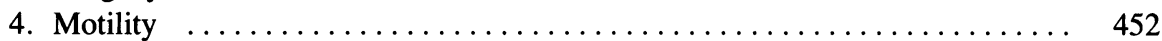

5. Toxicity of Tuftsin $\ldots \ldots \ldots \ldots \ldots \ldots \ldots \ldots \ldots \ldots \ldots \ldots \ldots \ldots \ldots \ldots, 452$

6. Immunogenic Activity .............................. 452

7. Antibacterial Effects of Tuftsin $\ldots \ldots \ldots \ldots \ldots \ldots \ldots \ldots \ldots \ldots \ldots, \ldots 53$

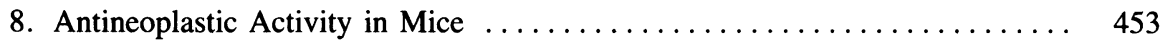

9. Restoration of Disease-Depressed and Age-Depressed Functions by Tuftsin .. 454

10. Effect of Tuftsin on Cyclic Nucleotide Levels $\ldots \ldots \ldots \ldots \ldots \ldots \ldots \ldots, 454$

11. Induction of Tumor Necrosis Factor by Tuftsin in Vivo and in Vitro ....... 455

12. Reactive Oxygen Compounds ........................... 455

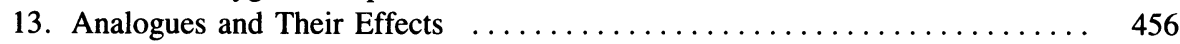

14. Molecular Mimicry between Receptor and Antibody ............... 457

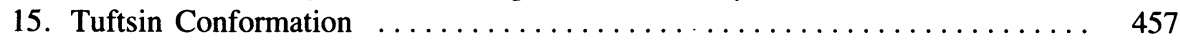

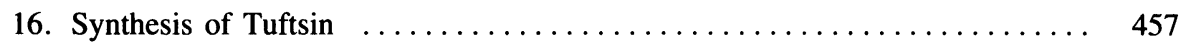

17. Methods for Synthesis of Radioactive Tuftsin . . . . . . . . . . . . . . . 458

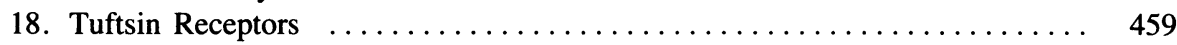




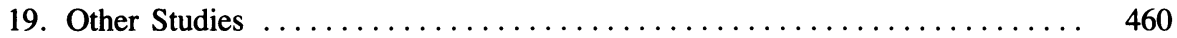

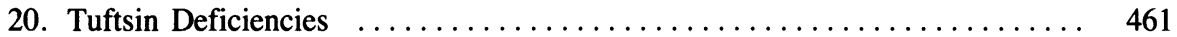

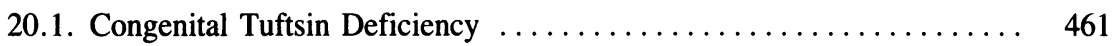

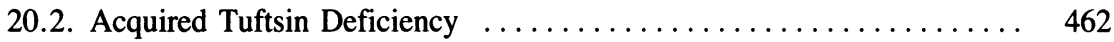

21. Mechanism of Action ............................ 462

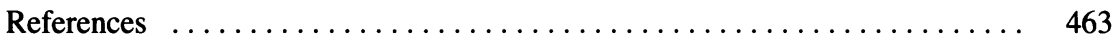

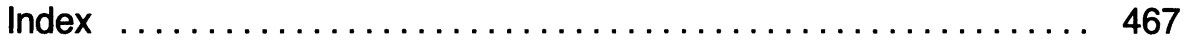




\section{The Respiratory Burst and Its Physiological Significance}

